\title{
The present, past and future of the study of intellectual disability: challenges in developing countries
}

Trevor R Parmenter BA, PhD. (I)

\begin{abstract}
Parmenter TR.
The present, past and future of the study of intellectual disability: challenges in developing countries. Salud Publica Mex 2008;50 suppl 2:SI24-SI3I.
\end{abstract}

\begin{abstract}
There is strong evidence that socio-cultural factors largely determine what is seen as competent behaviour.Within western high income countries, driven by the values of utilitarian individualism, the construct of intellectual disability has been largely determined to meet the needs of urban, industrialised societies. In contrast, competence in non-industrialised societies may be more reflected in collaborative, interpersonal problem solving skills such as those found among Nigerian students labelled as intellectually disabled. However, people who are judged to be incompetent or "obtrusive" in countries deficient in support services, are often neglected and consigned to a life in poorly managed segregated institutions, as is the case in China, Russia and some countries in Eastern Europe. Non western countries that have a long history of a globalised economy, such as Taiwan and Japan also remain committed to segregated institutional provisions for people with an intellectual disability, despite a notional acceptance of inclusionary policies enunciated by the United Nations' Declarations and Conventions. In this paper is concluded that it must be recognised that the population of people with an intellectual disability, regardless of how the condition is defined and classified, is quite heterogeneous. Their needs are also varied and not at all dissimilar to those of the general population. As developing countries adopt western style consumer-driven economies, there is an extreme danger that they, too, will follow the same trajectory of exclusion and impose the culture of "otherness" for a group whose contribution to that society will be devalued. Good science is futile unless it benefits all peoples.
\end{abstract}

Key words: intellectual disability; developing countries; challenges
Parmenter TR.

Pasado, presente y futuro del estudio de la discapacidad intelectual: desafíos en los países en desarrollo.

Salud Publica Mex 2008;50 supl 2:SI 24-SI3I.

\section{Resumen}

Existe amplia evidencia de que los factores socioculturales determinan en gran medida la percepción de conducta competitiva. En los países occidentales de altos ingresos, dominados por los valores del individualismo utilitario, las necesidades de las sociedades urbanas industrializadas han sido el principal determinante del concepto de discapacidad intelectual. A diferencia de esto, en las sociedades no industrializadas, la competencia puede verse mejor reflejada en las habilidades colaborativas, interpersonales para la resolución de problemas, tales como las que se encuentran entre estudiantes nigerianos considerados como intelectualmente discapacitados. Sin embargo, en los países deficientes en servicios de apoyo, a las personas consideradas incompetentes o "impertinentes" con frecuencia se les descuida y se les obliga a vivir en instituciones segregadas pobremente administradas, como por ejemplo en China, Rusia y en algunos países de Europa Oriental. Otros países no occidentales que tienen una larga historia de economía globalizada, como Taiwan y Japón permanecen igualmente fieles al modelo de instituciones segregadas para las personas con discapacidad intelectual, a pesar de una aceptación nominal de las políticas inclusivistas enunciadas por las declaraciones y convenciones de las Naciones Unidas. En este artículo se concluye que se debe reconocer la heterogeneidad que existe entre la población con discapacidad intelectual independientemente de cómo se defina y clasifique la condición. Sus necesidades son asimismo variadas y no disímiles respecto de las de la población general. En la medida en que los países en desarrollo adoptan economías de estilo occidental, orientadas hacia el consumo, existe un gran riesgo de que sigan también la misma trayectoria de exclusión y le impongan la cultura de la "otredad" a un grupo cuya contribución a esa sociedad sería devaluada. A menos que beneficie a todos la buena ciencia es inútil.

Palabras clave: discapacidad intelectual; países en desarrollo; desafíos

(I) Centre for Developmental Disability Studies, University of Sydney, Australia. 
$S^{\mathrm{c}}$ ientific inquiry into the nature and characteristics of intellectual disability has been heavily influenced by the history, culture, economy and politics of western industrialised countries. ${ }^{1}$ Because little is known about the place of people with a disability in developing countries, Ingstad $^{2}$ argued that a powerful mythology has arisen that implies that "non-western societies hide, abuse, and even kill their disabled family members" (p 774). The anthropologist, Robert Edgerton, ${ }^{3}$ who made extensive studies of attitudes towards people with an intellectual disability in a range of cultures concluded that:

So extreme is the dearth of existing data that most conclusions about the nature of mental retardation in these societies may remain quite speculative. Still, however inadequate these existing data may be, they are sufficient to call into question any notion that what is said or done about mental retardation in non-western societies is highly uniform from society to society. Quite the contrary is true. What is said and done is highly variable, so much that given the inadequacy of the present available data, it is difficult to generalise about this world at all. (p. 227)

Disappointingly, almost four decades later, no clear picture emerges concerning the place of a person with an intellectual disability within developing countries. It is intriguing that the very process of economic development brings into sharper relief the presence of people with lower intellectual functioning in socio-cultural settings.

What remains true, however, is the fact that it remains difficult to generalise the status of people with an intellectual disability across the vast range of countries with non western economies, where in many cases, extreme poverty is the basic defining characteristic. Even in western economies, poverty correlates significantly with the prevalence of intellectual disability. ${ }^{4}$

This paper will explore a number of western historical and contemporary influences on the study of intellectual disability that may have relevance for situations in developing countries. These include the conceptualisation of intellectual disability, philosophies and socioeconomic factors that have underpinned lines of inquiry. Research efforts in this field will be discussed within the context of the emerging needs of developing countries. It will conclude with suggestions as to how indigenous research efforts may be supported through collaborative partnerships with western initiatives.

\section{Conceptualisation of intellectual disability}

With the exception of people with severe multiple physical and mental disorders, the identification in western industrialised countries of large numbers of people with below average intellectual functioning coincided with the industrial revolution and the growth of public and universal schooling.

Scientific inquiry into the nature of intelligence can be traced back to antiquity in the writings of Hippocrates (460-559 BC) and Galen (131-200 AD). People born with "abnormal" physiognomy were treated with fear or ridicule. Pseudo scientific theories emerged such as palmistry and phrenology. A search for a cure for people who exhibited extreme aberrant behaviours gave rein to a wide range of treatments, many of which were related to the conviction that intellectual disability had its origins in demonic and satanic forces. "Moral training" was advocated as a way to exorcise the mental disorders of "moral imbeciles".

The "Age of Enlightenment" within the European context was stimulated by the writings of John Locke (1623-1704) who proposed the then radical belief in the value of education as a counter to the deeply held religious view of "men" having to bear the ineradicable stain of original sin. Despite a more enlightened approach to the value of rational thought, contemporary writers reflected the view that persons of lesser "intelligence" do not attain the same level of personhood as those of higher intellectual capacity. Thus began the concept of the "otherness" which ascribes a lesser level of personhood and citizenship to people with diminished intellects. ${ }^{5-6}$

Despite such negativism, figures such as the French physician Edouard Seguin, who was to become one of the founders of the American Association on Mental Retardation (recently renamed the American Association on Intellectual and Developmental Disabilities), espoused a more optimistic view of the role education could play in improving the functioning of people with an intellectual disability. This view, which gained publicity in the mid nineteenth century, has strong supporters today including the celebrated United Kingdom researchers Ann and Alan Clarke. ${ }^{7}$

Indeed, in 1844, the Paris Academy of Science proclaimed that Seguin had solved the problem of "idiot education". ${ }^{8}$ The influence of the medico-psychologists such as Seguin, Guiggenbühl and Howe in the nineteenth century extended throughout much of the western world and into the early twentieth century.

The rising growth of the discipline of psychology in the early 1900s, particularly its emphasis upon assessment and classification of intellectual functioning, was to have a profound effect upon the provision of services for people with an intellectual disability, both good and bad. In 1905 Alfred Binet (1857-1911), the director of the psychology laboratory at the Paris Sorbonne, developed 
a scale to identify those children whose lack of success in normal classrooms suggested their need for some sort of special education. His scale consisted of a number of everyday problems of life involving reasoning processes. The tasks were arranged in an ascending order of difficulty, with an age level assigned to each task, giving rise to the concept of mental age, and subsequently, the notion of an intelligence quotient (IQ).

As with later versions, the content of the scale was closely related to the content of schooling and the goals of the educational curriculum. Like Seguin, Binet had a firm belief in the ability of pedagogy to improve the intellectual performance of people who were recommended for special education programs.

The subsequent growth of the IQ testing movement throughout the twentieth century within the western industrialised countries has been heavily influenced by social, political and economic forces, peculiar to the perceived needs of an industrialised economy. A more anthropological approach, as described by Cianciolo and Sternberg, ${ }^{9}$ suggested that "...people in different cultures may develop somewhat different intellectual abilities, depending on what types of intellectual competence are valued in their particular culture" (p. 22).

Since 1958 the American Association on Intellectual and Developmental Disabilities (AAIDD) has included "significant impairment to adaptive behaviours" in its definition of intellectual disabilities, ${ }^{10}$ in addition to subaverage results on tests of IQ (usually two standard deviations below the mean). In fact, Sternberg and Grigorenko ${ }^{11}$ did not consider that intelligence is a construct that can be easily separable from the construct of adaptive behaviour, a view also supported by Schalock. ${ }^{12}$ It has long been recognised that the development of cognitive function is an interaction between hereditary and environmental factors. ${ }^{13}$ Sternberg ${ }^{14}$ defined successful intelligence as "the balancing of analytical, creative and practical abilities to achieve success within a particular sociocultural context".

Competence and one's ability to navigate effectively within a culture depends very much upon the environmental contents of that culture. Emerson, Fujiura and Hatton ${ }^{15}$ suggested that:

most societies seem to construct competence in more socially and culturally situated terms, rather than an abstract conception of intelligence, with substantial diversity in these constructions according to the specific needs and cultural mores of different cultural groups... from a global context the provision of classification systems and services based on conceptions of intellectual disability may be misguided; classification systems and services starting from local conceptions of competence and the proper social role of a competent person may be more productive.

In summary, there is strong evidence that sociocultural factors largely determine what is seen as competent behaviour. Within western high income countries, driven by the values of utilitarian individualism, the construct of intellectual disability has been largely determined to meet the needs of urban, industrialised societies. In contrast, competence in non-industrialised societies may be more reflected in collaborative, interpersonal problem solving skills such as those found among Nigerian students labelled as intellectually disabled. ${ }^{16}$ However, as Emerson et a ${ }^{15}$ pointed out, people who are judged to be incompetent or "obtrusive" in countries deficient in support services, are often neglected and consigned to a life in poorly managed segregated institutions, as is the case in China, Russia and some countries in Eastern Europe. Non western countries that have a long history of a globalised economy, such as Taiwan and Japan also remain committed to segregated institutional provisions for people with an intellectual disability, ${ }^{17}$ despite a notional acceptance of inclusionary policies enunciated by the United Nations' Declarations and Conventions.

\section{The western institutional era}

There are reports that the Christian church in the Middle Ages was responsible for the development of institutions to care for homeless and disadvantaged people such as foundlings, people with leprosy and mental illness. The industrial revolution and the subsequent movement of people from agrarian to urban living led to the development of "work houses" and the enactment of Poor Laws in mid nineteenth century England. While these developments did not address people with an intellectual disability specifically, many of this population became victims of the industrialisation era.

Influenced by the Charles Darwin's publication in 1859 of the Origin of Species and the discoveries of the geneticist Gregor Mendel (1822-1884), a movement known as eugenics arose. This was to have a profound effect upon the lives of countless thousands of people in the Western world and beyond.

The "menace of the feebleminded" was a concept widely publicised in the early twentieth century by protagonists such as $\mathrm{H}$. H. Goddard, the director of research at the Vineland Training School for FeebleMinded Girls and Boys in New Jersey in the USA. Terms 
such as "morons", "idiots" and "imbeciles" were used to classify people according to the scores on Binet's newly developed tests. It was Goddard ${ }^{18}$ who first referred to Binet's scale as a test of "intelligence", which he saw as a single entity.

The fear that society's genetic pool would be threatened by the procreation of people deemed to be immoral, promiscuous and of criminal intent led to an overcrowding of institutions and the enactment of sterilisation laws in many countries including France, Sweden, Canada and the USA. Institutions, initially designed to protect and succour people on the margins of society, became places to isolate people seen as a threat to society.

This era further stigmatised and marginalised people with intellectual disability. Not only were they stigmatised, but they were abused and treated in grossly inhuman ways, even by the social and ethical standards of the day. The concept of the "otherness" of this population was further embedded into societal attitudes towards disability and to intellectual disability in particular.

\section{Deinstitutionalisation and the principle of normalisation}

In the 1960s two significant events occurred which have shaped developments in the western industrialised world in respect to the treatment and support of people with an intellectual disability. The first was the work of Niels Erick Bank-Mikkelsen, the dynamic leader of the Danish state mental retardation services. He was the driving force for the Danish law for mentally retarded citizens enacted in 1959. This law led to the downscaling of large isolated institutions and to a policy that supported the idea that people with an intellectual disability "should obtain an existence as close to normal as possible". ${ }^{19}$

The second event was the election of J. F. Kennedy as President of The United States of America and his initiatives, prompted by family experiences, to set up in 1961 the President's Committee for Mental Retardation (now the President's Committee for Intellectual Disability). ${ }^{20}$ President Kennedy expanded the role of University Affiliated Programs to include major research efforts into the area of intellectual disabilities and established key Research Centres on Mental Retardation. The President's Committee also initiated an enquiry into conditions prevailing in large institutions for people with intellectual disabilities.

In 1967, the Committee invited Bengt Nirje from Sweden to present the principle of normalisation and to describe his impressions from visits to institutions in the USA. He presented a paper entitled "The Normalisation
Principle and its Human Management" which was one of his first versions of the Normalisation Principle.

Bengt Nirje's contributions as the "Father of the Normalisation Principle" were strongly influenced by the earlier work of Bank-Mikkelsen who first coined the term "normalisation", Nirje enunciated several key components of how society should address the patterns of life of people with an intellectual disability, and for that matter all disabilities. In his most recent formulation, Nirje $\mathrm{e}^{19}$ stated that,

The normalisation principle means that you act right when making available to all persons with intellectual or other impairments or disabilities patterns of life and conditions of everyday living which are as close as possible to or indeed the same as the regular circumstances and ways of life as their communities (p. 16).

While the Scandavivian impetus gave a sound basis for the deinstitutionalisation movement, the work of Wolf Wolfensberge ${ }^{21}$ had a more profound effect upon a large number of western countries, especially the United States. Wolfenberger's focus was on the use of normative means to establish normative behaviours in people with an intellectual disability. His approach emphasised the need for people with intellectual disability to adapt to the cultural norms of their community in much the same way as advocated by Goffman. ${ }^{22}$ Goffman defined the concept of "passing" as the ability of members of deviant groups to minimise their differences or signs of deviance so they are able to 'pass' undetected into society. Whereas Nirje's formulation emphasised freedom of choice and recognition of a person's integrity; in the context of the realities of life, Wolfenberger stressed the appearance of conformity and passing and the need for people to hide their deviancy. In the context of the earlier discussion on 'otherness' one might argue Wolfensberger's approach was more pragmatic. Wolfensberger ${ }^{23-24}$ reformulated his approach to normalisation by developing the theory of social role valorization ( $S R V$ ), which subsumed and replaced the principle of normalisation he had enunciated earlier. The new formulation placed strong importance on the concept of 'deviant' groups obtaining valued roles in society.

\section{Human rights and legislation}

In 1964, Harvey Stevens, in his presidential address to the First Congress of the International Association for the Scientific Study of Intellectual Disabilities (IASSID -then known as the International Association for the Scientific Study of Mental Deficiency) held in Montpellier, France, expressed the principle of the inalienable right of people with an intellectual disability to the same dignity 
as fellow human beings. In 1971, the General Assembly of the United Nations ${ }^{25}$ issued the Declaration of General and Specific Rights of the Mentally Retarded. This provided a moral justification for legislation that was enacted by governments of several western countries, promising opportunities for people with intellectual disabilities to be a part of normal society. In 1975, the Declaration on the Rights of Disabled People ${ }^{26}$ was proclaimed and 1981 was celebrated as the "Year of the Disabled". The years 1983-1992 were proclaimed as the "Decade of Disabled Persons". The period 1993-2002 was designated as the Asian "Decade of Disabled Persons" and the years 2003-2012 as the Asian Pacific "Decade of Disabled Persons". These initiatives have been supported by the UN Economic and Social Commission for Asia and the Pacific (ESCAP).

In the USA the Civil Rights Movement can be credited for an upsurge of legislation supporting the rights of people with disabilities to access employment and community based living. ${ }^{27}$ The enactment of Section 504 of the Rehabilitation Act in 1973 prohibited discrimination against people with disabilities by any entity in receipt of federal funds. This law was a precursor to the passage of the Americans with Disabilities Act in 1990. The passage of the Education for All Handicapped Children Act of 1975, which guaranteed children and youth with disabilities the right to fee, appropriate, public education, gave a new generation of parents the opportunity to demand related community services such as non segregated schooling, employment and community living options.

From the 1970s onwards, a series of federal class actions in the USA courts were mounted concerning the intolerable institutional living conditions of people with intellectual disabilities. In many states of the USA, institutions have closed, but significant numbers remain in segregated accommodation, as is the case in countries such as France, The Netherlands and Australia.

Legislation has been a vehicle for ending discriminative practices against people with disabilities in many other western countries, including the Nordic countries, the United Kingdom, Australia and New Zealand. In the United Kingdom a significant White Paper, Valuing People - a New Strategy for Learning Disability for the $21^{\text {st }}$ Century was presented to its Parliament in 2001. This paper sets out policy initiatives designed to raise the quality of life of people with intellectual disabilities across the United Kingdom.

Advocacy groups for people with disability; especially Inclusion International in the case of intellectual disability, have been tireless in their lobbying of the United Nations to support the rights of disabled people. In 1993 the Standard Rules on the Equalisation of Opportunities for Persons with Disabilities ${ }^{28}$ was adopted. This document outlined the need for people with a disability to have equal rights to services such as education and employment as the rest of society.

The most recent activity of the United Nations in the area of disability policy was the signing in New York, on 30 March 2007, of the Convention on the Rights of Persons with Disabilities. ${ }^{29}$ The detailed discussion on the content of the Convention have included people with an intellectual disability, representing the People First Movement which includes members from several countries including the United Kingdom, USA, Canada, New Zealand and Australia. Despite its international focus, the self-advocacy movement does not have a significant presence in developing countries.

While many countries have endorsed the declarations and conventions that have been promulgated by the United Nations, their translation into practice has been less than successful, even in rich high income countries. Reinders ${ }^{30}$ has argued that the moral language of rights is neither sufficient nor necessary to ground moral responsibility for people with a disability. He suggested that,

Without people who have sufficient moral character to care, rights can do little to sustain the mentally disabled and their families. People can be forced to comply, but they cannot be forced to care. (p. 23)

Nirje $^{31}$ commented that,

Laws and legislative work cannot provide total answers to problem solving and proper actions with regards to realisation of human rights. These can only come into existence in the full cultural and human context. Such problems are not only practical, but also ethical. (p. 65)

The rights movement that has resulted in legislation in many countries has provided a base for the provision of better supports to people with an intellectual disability. However, even in those countries, supports still fall far short of what the rights movement is proclaiming. In most cases the political will has not been there to effect the realisation of equality. As Emerson, et a ${ }^{15}$ and Parmenter $^{32}$ have argued the dominant values of high income societies have been characterised as highly individualistic and utilitarian. One might hope, that as developing countries become more economically sound, they will not lose the values that emphasise interdependence and collectivist communal relationships. It is these values, that will help to provide and sustain a 
quality of life for people with disabilities, in contrast to the western trend towards a commodification of people on the margins of society.

\section{The contributions of science}

A. E. Tredgold, one of the trail blazers of scientific inquiry into intellectual disabilities wrote in 1937 about the great advances which had taken place in the past thirty or forty years. He was also of the view that "mental deficiency" was a serious social problem that required the active involvement of medical practitioners and officials of public bodies. Significant advances were made in the first half of the twentieth century in the study of etiology of intellectual disabilities and possible ways of prevention, but there was an absence of research into ways of improving the health and quality of life of these people. Almost all of the research was conducted by medical practitioners, large numbers of whom were either members of Eugenics Societies or were sympathetic to their activities.

Lionel Penrose, a renowned geneticist, was to have a much more significant impact upon the lives of people with an intellectual disability. In his 1938 Classical Colchester (UK) Survey, ${ }^{33}$ he demonstrated the multiple etiologies of intellectual impairment. In his preface to Penrose's The biology of mental defect, ${ }^{34}$ another famous British scientist, John Burdon Sanderson Haldene, observed that Penrose's contribution to the study of human biology was as much a contribution to general culture, as it was to the study of incomplete human development. ${ }^{35}$

By 1963 Penrose $^{36}$ reported that specific health interventions involving hormonal, dietary and exercise treatments were helping to ameliorate the effects of cognitive impairments. At about this time there was a growing perception that people with an intellectual disability could also profit from educational programs, a view Seguin held over a century earlier. Researchers on both sides of the Atlantic Ocean were working on medical, educational and psychological issues, but in isolation. In an attempt to bridge this deficit, international conferences on intellectual disability were held in London, Vienna and Copenhagen in 1960, 1961 and 1964 respectively. At the Copenhagen conference the International Association for the Scientific Study of Mental Deficiency was formed (IASMD, now IASSID). Subsequent international congresses were held every three years. The early congresses were noted for their clear division between medical and non medical presentations.

The growing deinstitutionalisation movement and the impact of scientific research in the areas of education and psychology saw a growing optimism that people with an intellectual disability could be taught independent living skills that would enable them to get employment and live semi-independently in natural communities. ${ }^{37}$ The call for children with disabilities to be integrated into regular school classes was also supported by developments in instructional technology and assistive communication devices.

As noted above, the USA President's Panel on Mental Retardation was responsible for significant initiatives in research. The Panels' first report submitted in 1962 led to the passing of far-reaching legislation that authorised significant Federal funds for research. The establishment of the Hester Adrian Research Centre at the University of Manchester in 1967 and the establishment of the National Institute of Child Health and Human Development (NICHD) in the USA, were followed by the development of university affiliated research centres in other high income countries.

Over the forty years of the activities of IASSID, there has been a gradual reflection of multi-disciplinary and interdisciplinary collaboration among researchers in the field of intellectual disabilities. Basic research in all disciplines continues, but one of the more notable functions of IASSID has been its encouragement of research into specific need areas such as physical and mental health, community living, families, employment, education, communication, ageing, and quality of life. In each of these areas Special Interest Research Groups (SIRGs) have been formed to stimulate cross disciplinary research and to encourage research into practice (see www.iassid.org).

Disappointingly, even in the high income countries, the translation of research into practice has been slow. There has been a waning of government and societal commitment for change that was evident in the 1960s to 1980 s. The shift to utilitarian individualistic and economic rationalist social policies is possibly the main contributor to the slow implementation of research evidence into practice. ${ }^{32}$

Despite the enthusiasm for inclusive policies fostered by the deinstitutionalisation movement, there is a need to investigate how the policies of school inclusion and community living may be effected successfully to enable sound quality of life outcomes to be achieved for all people with intellectual disabilities. The moral and ethical implications of the tremendous breakthroughs in the human genome project present challenges for the field of intellectual disability in all countries. Again economic considerations play a critical role in the way new discoveries are made available for all sections of the community. Even in very rich countries, such as the USA, there are enormous disparities in the delivery of universal health care. 


\section{Implications for developing countries}

Given the need to understand the cultural contexts of how intellectual disability is defined in different countries, it is imperative that research in all countries be driven by local initiatives. For many of the developing countries, the provision of basic education and health services to their populations remains the most significant challenge they face. Related to this is their lack of trained personnel who can support the more marginalised groups in their communities. This is not a phenomenon peculiar to developing countries, for this situation has parallels in many high income nations.

In a true spirit of globalisation, high income countries have been assisting research efforts in a number of developing countries. What is especially relevant, however, is that we must avoid the risk of imposing western "solutions" in countries with quite different cultural and social histories. ${ }^{38}$

The development by IASSID of Regional Groups in Europe, Asia-Pacific and South America is assisting to connect researchers from the high and low income countries through the mounting of regional congresses. This initiative is helping to stimulate joint research efforts and a mentoring of younger researchers in the developing countries in those regions.

However, as Ingstad ${ }^{2}$ has warned, globalisation is bringing about dramatic social changes in traditional cultural patterns in the developing world. There are positives and negatives in these developments. She suggested that,

The emphasis on personal achievement and career easily comes into conflict with traditional values of family support and caregiving. Young people no longer rate family obligations as their highest priority but are more concerned with achieving consumer goods and personal success (p. 789).

But Ingstad also saw the positive side where education may give persons with a disability, "new possibilities for competence and a respected place in society" (p. 789).

Many of the low income countries around the world are facing huge economic problems, the major one of which is the extent of poverty and its related effects. Economic gains that are made have tended to widen the gap between the rich and the poor. World Trade Organization rules still tend to benefit richer rather than poorer countries. Problems that impact upon individual, family, community and government levels, such as the ravages of HIV / AIDS and internal conflicts and warfare reduce resources that might have helped to improve the quality of life of people with a disability. ${ }^{38}$

There are lessons to be learned from the experiences of high income countries. The emancipation of people with an intellectual disability has parallel to some extent the gains made by people with a physical or sensory disability who are generally more articulate. However, governments have tended to adopt a silo approach in their administration of support services, a practice that has to some extent isolated and hence maintained a segregationist mentality. It is suggested that a more effective approach is to encourage government and development agencies to mainstream disability into all support programs and to work towards universal accessibility. In order not to lose sight of the special needs people with an intellectual disability have above those of the regular population, one of the first steps should be to collect reliable data on the extent of the population that needs special support. If this information is fed into overall plans for health, education, housing, transport and other services; people with disabilities in developing countries will not have to go through the same patterns of exclusion that were typical of developments in the western world. This is also relevant to research efforts.

For example, people with an intellectual disability present quite complex health needs, that must be addressed through interdisciplinary research efforts including both mainstream and specialised scientists.

Above all, it needs to be recognised that people with disabilities, generally, are an integral part of all societies. With demographic trends towards greater life expectancy for all people as a result of better public health outcomes, the proportion of those with some form of disability within their life span will increase. Preventive measures will help to decrease the proportion of those with an intellectual disability, but science has not yet solved all the genetic and metabolic complexities and environmental factors that lead to a small but significant proportion of people in any society having an intellectual disability.

In conclusion, it must be recognised that the population with an intellectual disability, regardless of how the condition is defined and classified, is quite heterogeneous. Their needs are also varied and not at all dissimilar to those of the general population. As developing countries adopt western style consumer-driven economies, there is an extreme danger that they, too, will follow the same trajectory of exclusion and impose the culture of "otherness" for a group whose contribution to that society will be devalued. Good science is futile unless it benefits all peoples. 


\section{References}

I. Parmenter TR. Intellectual disabilities - quo vadis? In: Albrecht GL, Selman KD, Bury M, eds. Handbook of disability studies. Thousand Oaks, California: Sage Publications, 200I; 267-296.

2. Ingstad B. Disability in the developing world. In: Albrecht GL, Selman KD, Bury M, eds. Handbook of disability studies. Thousand Oaks,

California: Sage Publications, 200I; 772-779.

3. Edgerton RB. Mental retardation in non-Western societies:Towards a cross-cultural perspective on incompetence. In: Haywood HC, ed. Social cultural aspects of mental retardation. New York: Appleton-CenturyCrofts, 1970; 227-237.

4. Emerson E. Poverty and children with intellectual disabilities in the world's richer countries. J Intellect Dev Disabil 2004;29:319-338.

5. Edwards SD. The moral status of intellectually disabled individuals. J Med Philos 1997;22:29-42.

6. Edwards SD. The body as object services the body as subject:The case of disability. Med Health Care Philos 1998;1:47-56.

7. Clarke A, Clarke A. Human resilience. A fifty year quest. London: Jessica Kingsley; 2003.

8. Baumeister AA. The American residential institution: Its history and character. In: Baumeister AA, Butterfield E, eds. Residential facilities for the mentally retarded. Chicago:Aldene, 1970; I-28.

9. Cianciolo AT, Sternberg RJ. Intelligence. A brief history. Malden, MA: Blackwell Publishing; 2004.

10. Heber R. ed.A manual on the terminology and classification in mental retardation. Monograph supplement. Am J Ment Defic 1958: 64(2).

I I. Sternberg RJ, Grigorenko EL. Are cognitive styles still in style? Am Psychol 1997;2:700-712.

12. Schalock RL. Adaptive behaviour: Its conceptualisation and measurement. In: Emerson E, Hatton C, Thomson T, Parmenter TR, editors. The International handbook of applied research in intellectual disabilities. Chichester:John Wiley \& Sons Ltd, 2004;369-384.

13. Berry JW. An ecological perspective on the development of competence. In: Sternberg RJ, Grigorenko EL, eds. Culture and competence. Washington, D.C:American Psychological Association, 2004. 14. Sternberg RJ.The theory of successful intelligence. Rev Gen Psychol 1999; 3:292-316.

15. Emerson E, Fujiura G, Hatton C. International perspectives. In: Odom SL, Horner RH, Snell M, Blacher J, eds. Handbook of developmental disabilities. New York: Guildford Press; 2007.

16. Edeh OM, Hickson L. Cross cultural comparison of interpersonal problem-solving in students with mental retardation. Am J Ment Retard 2002;107:60-15.

17. Chou YC, Schalock RL. Trends in residential policies and services for people with intellectual disabilities in Taiwan. J Intellect Disabil Res 2007;5|:|35-|4|.
18. Goddard HH. The Kallikak family: A Study of heredity of feeblemindedness. New York: Macmillan; 1912.

19. Nirje B.The normalisation principle papers. Uppsala, Sweden: Centre for Handicapped Research, Uppsala University; 1992.

20. Alexander D. The impact of national policies on research in mental retardation - a United States perspective. ANZ J Dev Disabil 1988;14:183-188.

21.Wolfenberger W. The principle of normalization in human services. Toronto: National Institute on Mental Retardation; 1972.

22. Goffman E. Stigma: Notes on the management of a spoiled identity. Englewood Cliffs NS: Preston Hall; 1963.

23. Wolfenberger W. Social role valorization: A proposed new term for the principle of normalization. Ment Retard 1988;21:234-239.

24. Wolfenberger W. A brief overview of social role valorization. Ment Retard 2000;38:105-123.

25. United Nations. Declaration of general and specific rights of the mentally retarded. New York; 1971.

26. United Nations. Declaration of rights of disabled people. New York; 1975.

27. Braddock DL, Parish SL. An institutional history of disability. In: Albrecht GL, Seelman D, Berry M, eds. Handbook of disability studies. Thousand Oaks, California: Sage Publications, 200 I; I -68.

28. United Nations. Standard rules on the equalization of opportunities for persons with disabilities. New York; 1993.

29. United Nations. Convention on rights of people with disability. New York; 2007.

30. Reinders HS. The future of the disabled in liberal society: An ethical analysis. Notre Dame IN: University of Notre Dame Press; 2000.

3I. Nirje B. The basis and logic of the normalization principle. ANZ J Dev Disabil 1985;1 I:65-68.

32. Parmenter TR. Are we engineering ourselves out of existence? J Intellect Dev Disabil 2005;30:53-56.

33. Penrose LS.A clinical and genetic study of $I, 280$ cases of mental defect (Colchester Survey). Special Report Series, Medical Research Council, No 229, London: HMSO; 1938.

34. Penrose LS. The biology of mental defect. New York: Greene \& Statton; 1948.

35. Parmenter TR. The contribution of science in facilitating the inclusion of people with intellectual disability into the community. J Intellect Disabil Res 2001; 45:183-193.

36. Penrose LS. The biology of mental deficit. 2nd ed. New York: Grune \& Strattie; 1963.

37. Parmenter TR. Historical overview of applied research in intellectual disabilities:The foundation years. In: Emerson E, Hatton C, Thompson T, Parmenter TR, eds. The international handbook of applied research in intellectual disabilities. Chichester: John Wiley \& Sons Ltd, 2004; 3-39. 38. Albrecht GL, ed. Encyclopedia of disability. Volume I.Thousand Oaks, CA: Sage Publications; 2006. 